University of Nebraska - Lincoln

DigitalCommons@University of Nebraska - Lincoln

Nebraska Game and Parks Commission -- Staff

Research Publications

Nebraska Game and Parks Commission

January 1984

\title{
Trophic Dynamics of a Nebraska Black Crappie and White Crappie Population
}

\section{Daryl G. Ellison}

Lake McConaughy Fisheries Research Laboratory, Nebraska Game and Parks Commission, Ogallala, Nebraska

Follow this and additional works at: https://digitalcommons.unl.edu/nebgamestaff

Part of the Environmental Sciences Commons

Ellison, Daryl G., "Trophic Dynamics of a Nebraska Black Crappie and White Crappie Population" (1984). Nebraska Game and Parks Commission -- Staff Research Publications. 20.

https://digitalcommons.unl.edu/nebgamestaff/20

This Article is brought to you for free and open access by the Nebraska Game and Parks Commission at DigitalCommons@University of Nebraska - Lincoln. It has been accepted for inclusion in Nebraska Game and Parks Commission -- Staff Research Publications by an authorized administrator of DigitalCommons@University of Nebraska - Lincoln. 


\title{
Trophic Dynamics of a Nebraska Black Crappie and White Crappie Population ${ }^{1}$
}

\author{
DARYL G. ElLISON \\ Lake McConaughy Fisheries Research Laboratory \\ Nebraska Game and Parks Commission \\ Ogallala, Nebraska 69153
}

\begin{abstract}
Diet variations of black crappie (Pomoxis nigromaculatus) and white crappie (Pomoxis annularis) were investigated at Hayes Center State Lake, a turbid 20-hectare state lake in southwest $\mathrm{Ne}$ braska. Zooplankton and insects accounted for most of the diet of all black crappie and of white crappie less than $200 \mathrm{~mm}$ long. The daily ration of planktophagic crappie declined to $1.3 \%$ as both species approached a length of $200 \mathrm{~mm}$. Black crappie longer than $200 \mathrm{~mm}$ did not convert to fish and the daily ration declined to $0.8 \%$. The dietary shift of white crappie to fish significantly increased the average volume of food as the daily ration increased to 1.6 and $2.9 \%$ at $200-249$ and $\geq 250 \mathrm{~mm}$, respectively. Crappie growth and survivorship were affected by the nature of the food. White crappie were 2.4 times more numerous and grew faster with improved survival at Age IV compared to the less dense black crappie population. Mortality rates of black crappie related positively to their size and water temperature during the growing season. Many black crappie longer than $200 \mathrm{~mm}$ died during July and August at 26-28 C; 71, 89, and $100 \%$ mortality of respective 200-209, 210-219, and 220-229 mm black crappie was estimated during summer. Black crappie ( $\geq 200 \mathrm{~mm}$ ) were less adapted to capturing fish in turbid water, resulting in an energy trap during summer. The ability of $\geq 200$ - $\mathrm{mm}$ white crappie to prey on fish increased the daily ration above maintenance level during summer.
\end{abstract}

Crappie (Pomoxis sp.) are highly sought after by anglers and provide countless hours of fishing in all seasons of the year. Good crappie fishing is typical in new impoundments for several years and for sustained periods in certain lakes. Management of crappie has focused on liberal harvest regulations and the removal of excessive numbers of intermediate-size fish to improve the growth rate of the remaining crappie population (Rutledge and Barron 1972). This practice seemed to treat the symptoms of the problems of poor crappie fishing, but increasing the food supply as well as reducing the population size also has been considered (Goodson 1966).

High crappie recruitment and slow growth of fish under $200 \mathrm{~mm}$ in length during the third or fourth year of life, followed by high mortality with few surviving to Age V, is a frequent scenario in lakes with crappie populations. Identifying the problem of high mortality involves rec-

\footnotetext{
${ }^{1}$ Presented in a symposium entitled "Crappie Management: Problems and Solutions" at the 44th Midwest Fish and Wildlife Conference at Des Moines, Iowa on December 12-15, 1982. The symposium was sponsored by the North Central Division, American Fisheries Society.
}

ognizing both the absolute quantity of ingested rations per fish as well as the processes reflected in growth efficiency (the fraction of rations utilized for growth). The relation of ration level of fishes and growth efficiency, coined "K-line" by Paloheimo and Dickie (1965), and the interactions among temperature, fish size, and total metabolism are complex and difficult to define in fisheries systems. The most important element affecting growth efficiency in nature, however, is the metabolic cost of feeding activity or energy requirements when searching for prey (Kerr 1971). Prey size (weight of a single diet item), abundance, and vulnerability are determinants of growth efficiency, particularly when the energy cost of acquiring food is appreciable. As early as the 1940's, Bennett (1945) associated rapid growth of crappies with feeding on large food organisms.

Growth efficiency declines as crappie size increases and prey organisms are small in relation to the size of the predator. In crappie lakes where small zooplankton and small aquatic insects are the principal prey, growth efficiency decreases as crappie gain in weight. The maximum attainable length of crappie under these conditions is undesirable to the angler because food organisms 
are so small that the assimilated caloric "reward" does not exceed the "cost" of its capture. Crappie larger than about $150 \mathrm{~mm}$ are not highly adapted to feeding on small zooplankters because the larger spaces between gill rakers prevent the retention of food organisms (Wright et al. 1983). The lack of available fish for prey during transition from zooplankton is a critical missing link in some crappie predator-prey systems.

The black crappie (Pomoxis nigromaculatus) or the white crappie (Pomoxis annularis) usually predominates in lakes where both occur. Generally the former is more abundant in clear lakes and the latter seems better adapted to turbid waters (Hall et al. 1954; Neal 1963; Goodson 1966). Identifying some of the problems for slow growth and high mortality, as related to food and density of black crappie and white crappie in the same system, was limited by the frequently low abundance of one species. A lake was selected to identify the relationship of growth and survivorship to the nature of the food and relative abundance of black crappie and white crappie in the same lake where mortality by fishing and predation is reduced. The results are reported in this paper.

\section{Methods}

The diet of black crappie and white crappie was investigated at Hayes Center State Lake located $19 \mathrm{~km}$ northeast of Hayes Center in southwest Nebraska. This 20 -hectare lake is turbid (secchi disk readings $30-38 \mathrm{~cm}$; 65 JTU) due to suspended clay particles, shallow (maximum depth, $2 \mathrm{~m}$ ), and well buffered (total alkalinity, $290 \mathrm{mg} / \mathrm{liter}$ ). This isolated lake receives little fishing pressure. Black crappie, white crappie, bluegill (Lepomis macrochirus), and common carp (Cyprinus carpio) comprise most of the fish population. Largemouth bass (Micropterus salmoides), northern pike (Esox lucius), channel catfish (Ictalurus punctatus), and black bullhead (Ictalurus melas) are present in small numbers. The relatively few adult gizzard shad (Dorosoma cepedianum) produce large numbers of young; however, few young of the year survive overwinter.

A zooplankton sample was collected on $20 \mathrm{Au}$ gust 1979 by taking a 5-minute horizontal haul at mid-depth in the center of the lake using a 0.5 -m diameter nylon net with 505 micron mesh. The sample was preserved in $100 \%$ isopropyl alcohol and returned to the laboratory. Body lengths from 640 zooplankton were measured from the anterior margin of the head to the base of either the tail spine of cladocerans or the caudal rami of copepods under a dissecting scope.

Age-I and older crappie were sampled by trap netting for 3 days each during the third week of June, August, and October 1979 and young-ofthe-year crappie were collected by shoreline seining for analysis of seasonal food habits. Nets were set by 0900 hours and run about every 1-2 hour until dark. Frame nets were used that consisted of $16-\mathrm{mm}$, square-mesh nylon, a lead $15.2 \times 0.9$ $\mathrm{m}$ attached to two $1.2 \times 0.9-\mathrm{m}$ frames, and seven $0.9-\mathrm{m}$ diameter hoops with two throats. The seine used was $15.2 \mathrm{~m}$ long by $1.2 \mathrm{~m}$ wide with $3-\mathrm{mm}$, square-mesh nylon and a $1.2 \times 1.2 \times$ $1.2-\mathrm{m}$ bag in the center. Individual fish were identified, sexed, and the total length (TL) and weight recorded. A scale sample was taken below the lateral line at the tip of the pectoral fin for age and growth determinations. Scale impressions were made on cellulose acetate and read on a microprojector.

The body-scale relationship of 170 black crappie was: $\mathrm{TL}=39.5572+1.9081 \mathrm{~S}(r=0.9800)$; for 215 white crappie, it was: $\mathrm{TL}=41.7118+$ $2.4503 \mathrm{~S}(r=0.9802)$. A direct-proportion method with a 40-mm constant intercept was used in back-calculating lengths at each annulus.

When the food in crappie stomachs appeared to be at a maximum for the day, individual stomachs were preserved in $10 \%$ buffered formalin in a labeled container and returned to the laboratory for analysis. Up to 25 stomachs were taken during each sampling period from each of the following size groups from both species: $<100$ $\mathrm{mm} ; 100-149 \mathrm{~mm} ; 150-199 \mathrm{~mm} ; 200-249 \mathrm{~mm}$; and $\geq 250 \mathrm{~mm}$. Stomachs were analyzed in the laboratory individually under a dissecting scope and food items were identified, separated, and measured volumetrically $( \pm 0.05 \mathrm{ml})$ by centrifugation. A conversion of food volume from milliliters to grams was determined in the laboratory to be a $1: 1$ volume-weight relationship for fish as well as for zooplankton and insects. An IBM 370 computer was utilized for age, growth, and stomach data analyses. Seasonal variation in the diet of crappie was low and the data were combined for simplicity in analysis.

\section{Results}

The size composition of the zooplankton community appeared to be influenced by plankto- 


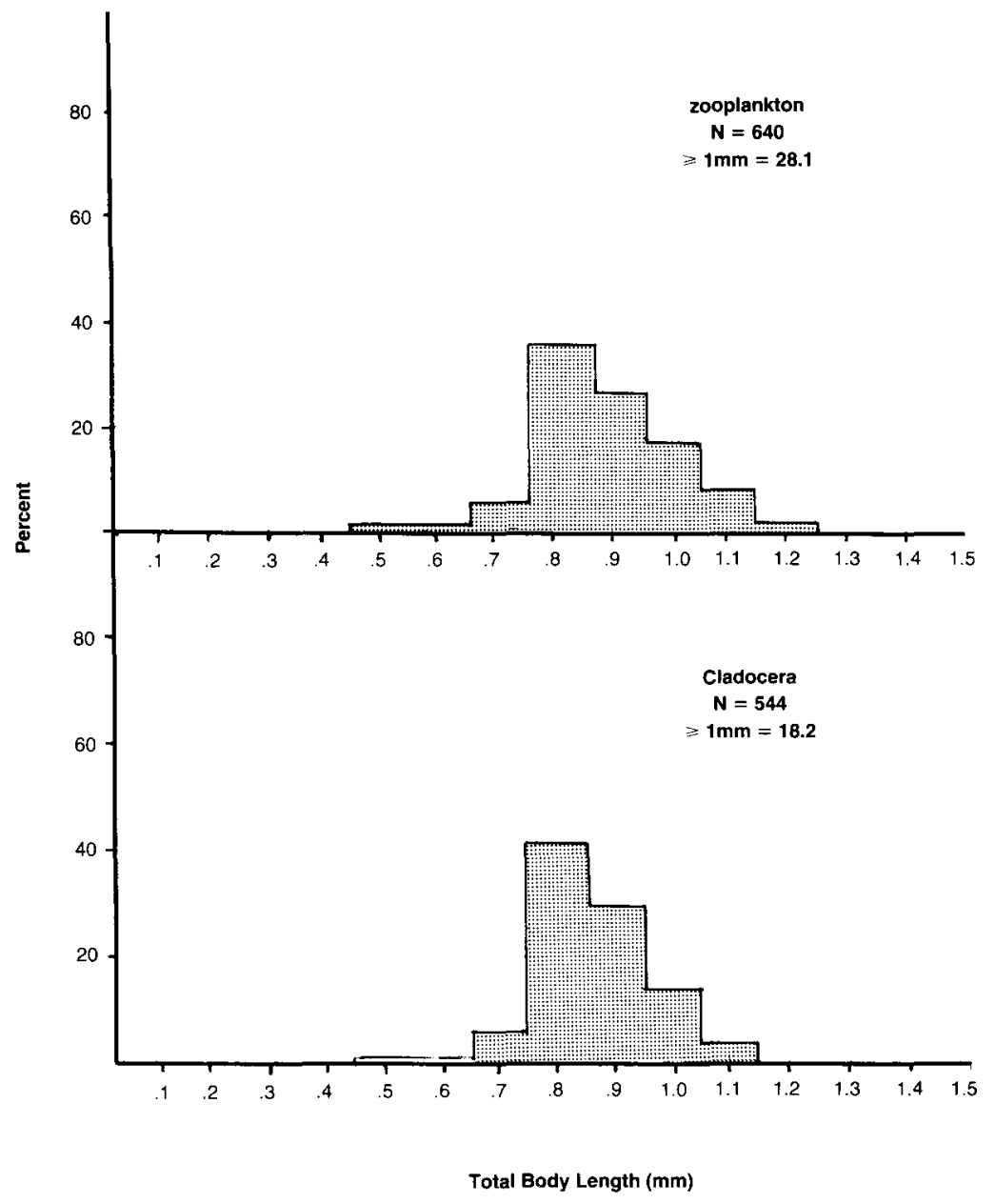

Figure 1. Length-frequency distribution of all zooplankton and cladocera taken in a horizontal plankton tow at Hayes Center State Lake, Nebraska, 20 August 1979.

phagic crappie as well as turbidity. Crustacean zooplankters were limited to $1.2 \mathrm{~mm}$ in length, with a majority between $0.8-1.1 \mathrm{~mm}$ (Fig. 1). Although $18.2 \%$ of cladocerans (mostly daphnids) over $0.5 \mathrm{~mm}$ were $\geq 1 \mathrm{~mm}$, none were larger than $1.1 \mathrm{~mm}$. It should be recognized that the sample was limited to zooplankton greater than $0.4 \mathrm{~mm}$ because of mesh size. Daphnia $(>0.7$ $\mathrm{mm}$ ) and Bosmina $(<0.5 \mathrm{~mm})$ constituted most of the cladocerans in crappie stomachs; thus, zooplankters less than $0.5 \mathrm{~mm}$ long were present but passed through the net.

Zooplankton and insects accounted for most of the diet of black crappie and white crappie less than $200 \mathrm{~mm}$ long (Figs. 2 and 3). Cladocera made up a majority $(55-83 \%$ by volume) of the zooplankton ingested by crappie and corixids (water boatmen) were, by volume, the most important insect utilized. The most significant variation was the transition from zooplankton to fish by white crappie greater than $200 \mathrm{~mm}$ (Fig. 3). Fish comprised 64 and $93 \%$ by volume of the total diet of 200-249 and $\geq 250 \mathrm{~mm}$ white crappie, respectively. Largemouth bass and gizzard shad each were found once in a stomach and only bluegill were identified in 5 of 27 white crappie that contained fish in their stomachs.

Diel feeding periodicities of crappies were apparent. Black crappie and white crappie less than $200 \mathrm{~mm}$ long were empty during mid-morning (0900-1100 hours), zooplankton and insects appeared in stomachs of fish taken around noon, 

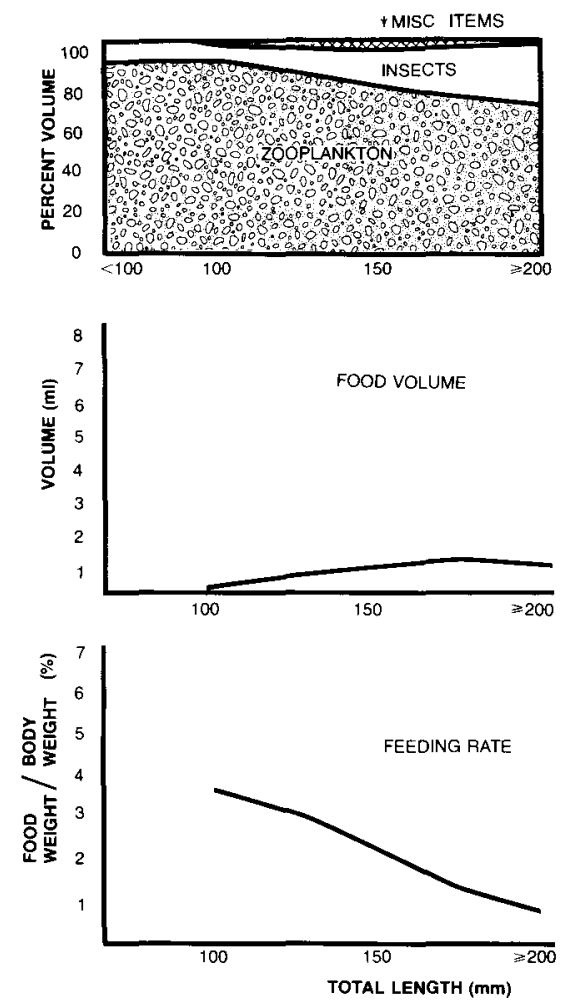

Figure 2. Diet, volume of food, and estimated feeding rates of black crappie of various sizes at Hayes Center State Lake, Nebraska, 1979.

and there was an increase of food in stomachs during the afternoon. The volume of food in the stomachs reached a maximum between 1500 and 1700 hours. The variability of food volume per stomach was low for crappie within each size group. The $95 \%$ confidence limits of the mean volume of food in stomachs ranged from $\pm 13 \%$ for $150-199 \mathrm{~mm}$ black crappie to $\pm 32 \%$ for $<100$ $\mathrm{mm}$ white crappie. Crappie diet had a significant influence on the volume of food ingested. Food in stomachs decreased in proportion to weight; the ratio of food weight to body weight declined from 3.7 to $0.8 \%$ as black crappie gained weight (Fig. 2). A similar trend was apparent for planktophagic white crappie; the ratio of food weight to body weight declined from 6.7 to $1.3 \%$ for $<100$ and 150-199 mm white crappie, respectively (Fig. 3). The transition to fish increased the average volume of food in white crappie stomachs to 2.0 and $8.4 \mathrm{ml}$ at $200-249$ and $\geq 250$ $\mathrm{mm}$, respectively. The ratio of food weight to
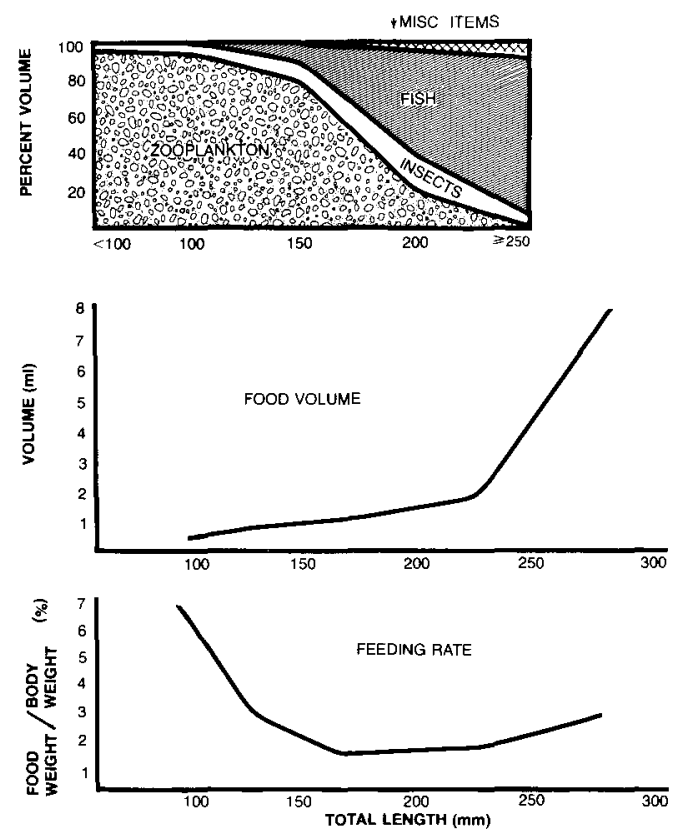

Figure 3. Diet, volume of food, and estimated feeding rates of white crappie of various sizes at Hayes Center State Lake, Nebraska, 1979.

body weight increased from $1.6 \%$ for $200-249$ $\mathrm{mm}$ fish to $2.9 \%$ for $\geq 250 \mathrm{~mm}$ white crappie (Fig. 3).

Growth and survivorship patterns were different for black crappie and white crappie. When crappie fed as planktivores, the weight of food in stomachs did not increase in proportion to gain in fish weight, limiting maximum age and percent of harvestable fish (Figs. 4 and 5). Size of age II-IV black crappie was significantly $(P<$ 0.01 ) less than age II-IV white crappie (Fig. 6). A more sensitive measure of growth illustrated the relation of growth to diet of crappie. When length increment (the previous year) was plotted as a function of initial length (at capture in June), growth rate of small crappies (120-149 mm) was similar (Fig. 7). White crappie grew faster than black crappie, however, at a size (about $150 \mathrm{~mm}$ ) when white crappie converted to a fish diet. Black crappie growth rates were slower and, equally as important, longevity was limited to Age IV (Fig. 6).

Mortality rates of black crappie related positively to fish size and water temperature during the growing season. Survival during summer and fall was estimated from a length frequency (\%) 

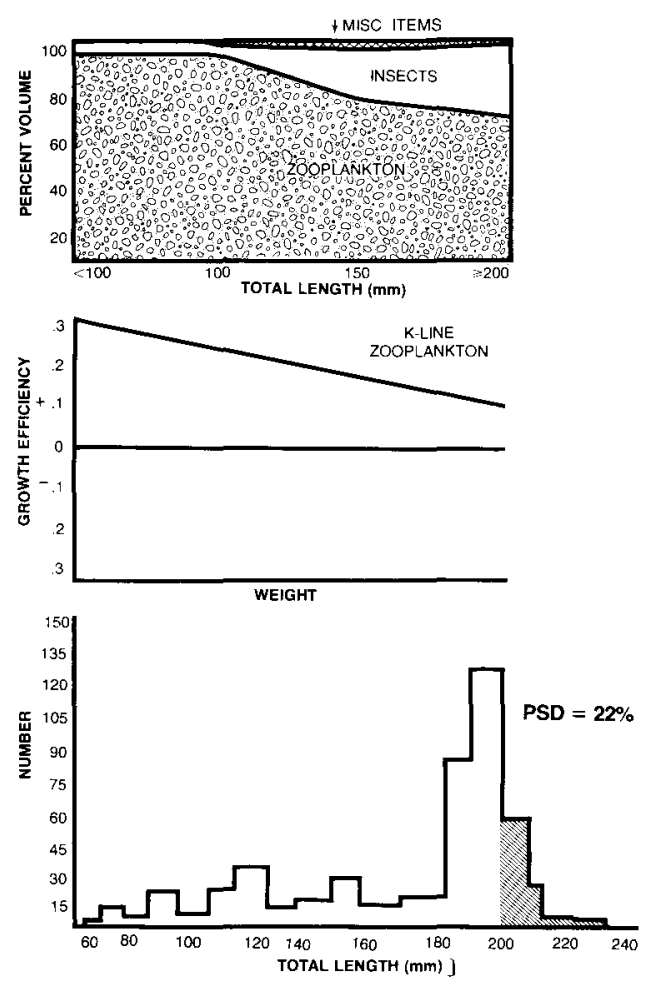

Figure 4. Diet, growth efficiency, and length frequency of black crappie of various sizes at Hayes Center State Lake, Nebraska, 1979. The K-line represents a hypothetical relationship of growth efficiency to diet and weight of black crappie. Shaded area relates to the PSD.

of $\geq 190 \mathrm{~mm}$ black crappie between June and August and August and October. The 60 days between samples accounted for $40 \%$ of the growing season (150-day, frost-free period). Approximately 9-14 mm of growth for $190-229 \mathrm{~mm}$ black crappie would be expected between sampling periods using a $23-35 \mathrm{~mm}$ annual length increment (Fig. 7). Using a $10-\mathrm{mm}$ average length increment between samples, mortality was greater during summer than fall, and significantly higher for black crappie longer than $200 \mathrm{~mm}$ in summer (Table 1). Most black crappie longer than $209 \mathrm{~mm}$ died during summer when 89 and $100 \%$ mortalities were estimated for $210-219$ and 220-229 mm black crappie, respectively (Table 1). Mortality rates were related to crappie size in the fall, although survival improved when water cooled to 9-17 C. Based on 1979-1981 age frequencies, the estimated annual mortality rates
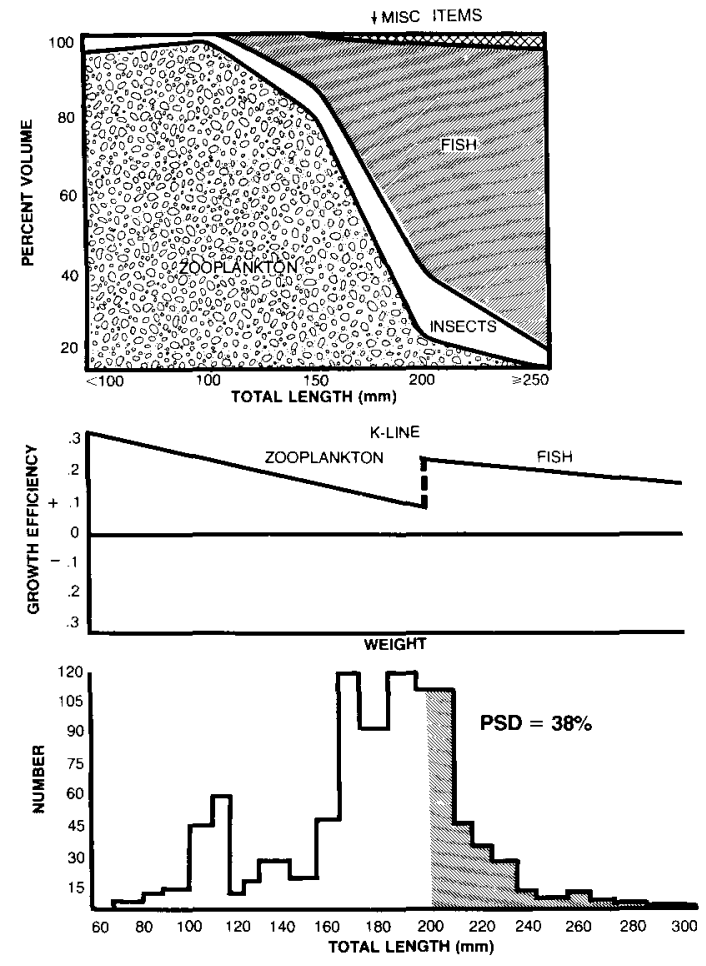

Figure 5. Diet, growth efficiency, and length frequency of white crappie of various sizes at Hayes Center State Lake, Nebraska, 1979. The K-line represents a hypothetical relationship of growth efficiency to diet and weight of white crappie. Shaded area relates to the PSD.

for black crappie were 59,84 , and $100 \%$ at ages II, III, and IV, respectively. Mortality rates were similar for age II and III white crappie but $15 \%$ survived after their fourth year. Annual mortality was estimated to be 54,84 , and $85 \%$ at ages II, III, and IV, respectively.

The lower mortality rate for Age-II fish was expected because growth efficiency of planktonfeeding crappie should be greater at a smaller size. Angler pressure and harvest were negligible so that fishing mortality had little influence on survival. In addition, few predators were large enough to prey on Age-II and older crappies. Age-I and older white crappie were 2.4 times more numerous than black crappie and accounted for $71 \%$ of 3,833 crappie collected so that intraspecific competition was greater. White crappie grew faster and lived longer than black crappie even though density was greater, with 


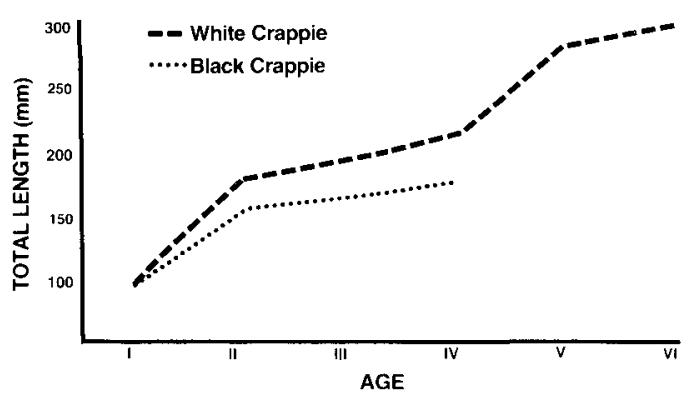

Figure 6. Average back-calculated total lengths (millimeters) of white crappie and black crappie at Hayes Center State Lake, Nebraska, 1979.

growth and survivorship into older age groups reflecting the dietary shift to fish (Fig. 5). The Proportional Stock Density (PSD) or proportion of fish sampled more than $200 \mathrm{~mm}$ long that were stock size $(\geq 130 \mathrm{~mm})$ was 22 for black crappie and 38 for white crappie (Figs. 4 and 5). Less than $1 \%$ of the black crappie and $11 \%$ of the white crappie sampled $(\geq 130 \mathrm{~mm})$ were acceptable to anglers if a $230-\mathrm{mm}(150 \mathrm{~g})$ or larger crappie is considered a harvestable size.

\section{Discussion}

The size composition of prey and the high turbidity of Hayes Center State Lake limited the volume of food in planktophagic crappie. The empty stomachs of crappie less than $200 \mathrm{~mm}$ long during the morning and digestive rates of crappie determined in other studies suggested that feeding activity at night was minimal. Food of young white crappies in Conowingo Reservoir, Pennsylvania passed through stomachs in about 14 to 17 hours at 25 to $29 \mathrm{C}$ surface temperatures (Mathur and Robbins 1971). About 80\% of the volume of food in black crappie stomachs was reduced in 14-19 hours in Grove Lake, Minnesota (Seaburg and Moyle 1964). Maximum volume of food in stomachs of planktophagic black crappie and white crappie in Hayes Center State Lake was first found at 1300 hours and mostly between 1500 and 1700 hours. Peak feeding activity of white crappie in Conowingo Reservoir also occurred in mid-afternoon (1500 hours) and declined by 1800 hours (Mathur and Robbins 1971). Black crappie fed more during the morning and the volume of food decreased in their stomachs during the afternoon in Grove Lake, Minnesota (Seaburg and Moyle 1964).
The observed feeding periodicity in Hayes Center State Lake suggests a long search time to locate prey, requiring most of the day for planktophagic crappie to complete a meal. Feeding rates are regulated by prey mobility, size, and density plus turbidity and light conditions. The reactive distance of crappie to 1-mm Daphnia was about $65 \mathrm{~mm}$ in aquaria (80 lux) (W. J. O'Brien, B. S. Loveless and D. I. Wright, unpublished). The low water transparency in Hayes Center State Lake may have limited a crappie's $(<200 \mathrm{~mm})$ visibility of its principal prey $(<1.2$ $\mathrm{mm}$ Daphnia) to $15 \mathrm{~mm}$ or less, significantly reducing feeding efficiency. The energy gained from zooplankton by black crappie greater than $200 \mathrm{~mm}(113 \mathrm{~g})$ long apparently did not offset the cost of capture, particularly during summer (26-28 C) when energy requirements were highest. Increasing mortality rates of $47,71,89$, and $100 \%$ by respective $10-\mathrm{mm}$ length groups $(190$, 200,210 , and $220 \mathrm{~mm}$ ) between late June and late August suggests that black crappie longer than $200 \mathrm{~mm}$ were in an energy trap during the summer. Adult crappie occasionally experienced high natural mortality during summer at Lake Chautauqua, Illinois (Starrett and Fritz 1965). Hanson (1951) also believed the disappearance of large white crappie was attributed to summer mortality at Lake Decatur, Illinois. The energy demand of a $200-\mathrm{mm}$ crappie approaches 700 calories per day at $25 \mathrm{C}$, requiring a daily feeding rate of more than 600 Daphnia per hour for a 12-hour period (W. J. O'Brien, B. S. Loveless, and D. I. Wright, unpublished). Even in clearer lakes, consistent feeding rates by large crappie at these temperatures probably would not exceed 350 prey per hour.

The limited feeding rate explains why the volume of zooplankton ingested did not increase appreciably as crappie gained weight. The growth rate of planktophagic black crappie and white crappie appeared to slow down upon attaining $150 \mathrm{~mm}(45 \mathrm{~g})$. The daily ration declined to $1.3 \%$ for 150-199 mm black crappie and white crappie, approaching maintenance levels. The daily ration of black crappie longer than $200 \mathrm{~mm}$ further decreased to $0.8 \%$; by white crappie shifting to fish, their feeding rate increased to 1.6 and $2.9 \%$ at $200-249$ and $\geq 250 \mathrm{~mm}$, respectively. Seaburg and Moyle (1964) observed a similar decline in daily ration level from about $2 \%$ for $150 \mathrm{~mm}$ to $<1 \%$ for black crappie greater than $200 \mathrm{~mm}$ in Grove Lake, Minnesota. Plankto- 


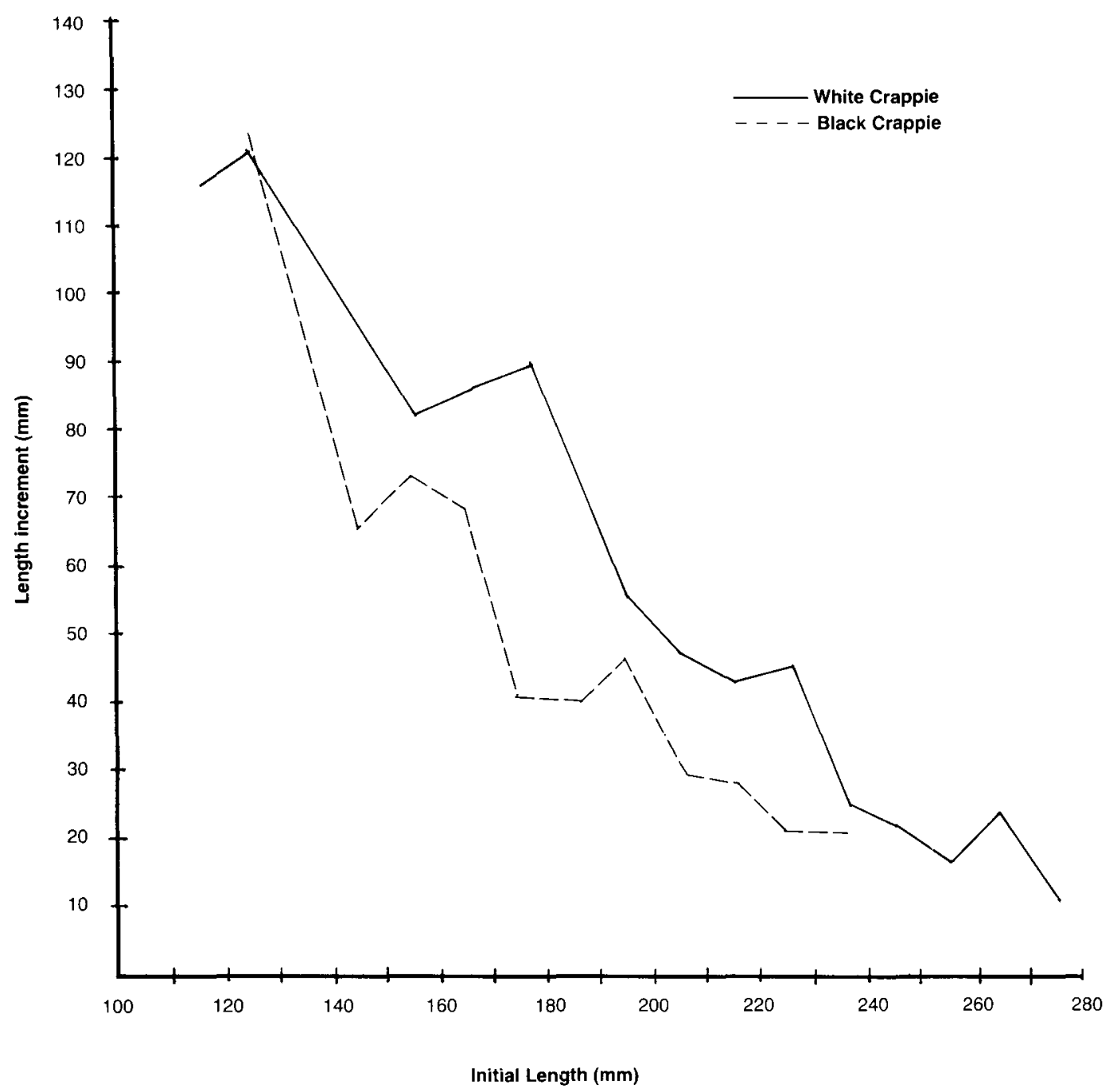

Figure 7. Length increment (the previous year) as a function of initial length (at capture) of white crappie and black crappie at Hayes Center State Lake, Nebraska, June 1979.

phagic black crappie and white crappie ingested less food per unit of body weight and, at the same time, the energy obtained from zooplankton was increasingly used for metabolic needs in Hayes Center State Lake.

Growth and survivorship patterns of black crappie and white crappie in this study paralleled the bluegill dynamics of balanced and unbalanced populations. Age-III and older bluegills grow faster and longevity is greater in balanced populations (Anderson 1973). High mortality of Age-II and older bluegill limits their life span to Age- $\mathrm{V}$ in unbalanced populations, although some bluegills live for 8 yéars in balanced populations. However, population density did not relate to the growth and survivorship curves of the abundant black crappie and white crappie stock in Hayes Center State Lake.

Crappie recruitment and mortality rates influence intra- and interspecific competition. If recruitment were not excessive, the potential average ration available per crappie would increase. Crappie growth would be limited, however, by the bounds imposed by the nature of the food resource (prey size and density). However, a lower population density may have little influence 
Table 1. Seasonal length-frequency distribution (\%) and estimated survival (S) of $\geq 190$-mm black crappie at Hayes Center State Lake, Nebraska, in June, August, and October 1979.

\begin{tabular}{|c|c|c|c|c|c|c|c|}
\hline \multirow{3}{*}{$\begin{array}{c}\text { Length } \\
\text { interval } \\
(\mathrm{mm})\end{array}$} & \multicolumn{5}{|c|}{ Month } & \multirow{2}{*}{\multicolumn{2}{|c|}{ Average survival }} \\
\hline & \multirow{2}{*}{$\underset{(\%)}{\text { June }}$} & \multirow[b]{2}{*}{$S$} & \multirow{2}{*}{$\begin{array}{c}\text { August } \\
(\%)\end{array}$} & \multirow[b]{2}{*}{$S$} & \multirow{2}{*}{$\begin{array}{c}\text { October } \\
(\%)\end{array}$} & & \\
\hline & & & & & & Jun-Oct & Nov-May \\
\hline $190-199$ & 32.20 & & 44.03 & & 20.62 & & \\
\hline $200-209$ & 5.08 & & 17.16 & & 32.99 & & \\
\hline $210-219$ & 6.78 & & 1.49 & & 12.37 & -0.620 & 0.258 \\
\hline $220-229$ & 1.69 & & 0.75 & & -1.03 & -0.450 & 0.000 \\
\hline $230-239$ & 0.00 & & 0.00 & & 0.00 & -0.038 & 0.000 \\
\hline
\end{tabular}

on growth if prey size, feeding habits, and water transparency remain unchanged. Growth efficiency is low for 200-mm and larger crappie feeding on zooplankton. Despite a substantial improvement in average rations (zooplankton) available per crappie, the increased food would not be used efficiently when prey size is unchanged. Growth and survival was less for black crappie remaining as planktivores as compared to white crappie feeding on fish. The lower abundance of black crappie in turbid lakes and the fact they remain planktivorous in Hayes Center State Lake suggests less adaptation and ability to capture fish under these light conditions. Transition to fish is especially important for crappie $210 \mathrm{~mm}$ and longer during summer. Most planktophagic black crappie longer than $209 \mathrm{~mm}$ died during July and August when the energy demand at $26-28 \mathrm{C}$ surpassed the assimilated caloric gain from zooplankton. Age-III and older crappie (both species) grew little at $27 \mathrm{C}$ in Clear Lake, Iowa (Neal 1963).

A significant shift in the size composition of prey can improve feeding rate, growth, survival, and size structure of crappie populations, as evidenced by the response of black crappie and white crappie to variation in diet. Young-of-the-year bluegills and gizzard shad were available to crappie $200 \mathrm{~mm}$ and longer by late June. However, low vulnerability of bluegill as prey and/or their low visibility to crappie limited the value of this species in the diet. The effect of water transparency on prey visibility can be significant when the prey is composed of comparatively large but fewer organisms. The high turbidity of Hayes Center State Lake had less influence on growth and survival of small and intermediate $(<150$ $\mathrm{mm}$ ) black crappie and white crappie when they fed on zooplankton and insects. Reduced prey visibility may have had a sharp effect, however, on the feeding rate for bluegill and gizzard shad by the $200-\mathrm{mm}$ and larger planktophagic black crappie and white crappie.

\section{MANAGEMENT IMPLICATIONS}

By comparing factors governing the dynamics of crappie in problem lakes as well as in good populations, fish managers may discover tools to manage crappie. A number of irrigation reservoirs in western Nebraska have desirable black crappie and/or white crappie populations. The populations are characterized by consistent, annual recruitment, a moderate mortality of intermediate-size crappie, and relatively fast growth rates up to $230 \mathrm{~mm}$ long during the third year of life to produce good numbers of harvestable crappies. Slow growth rates of young-of-the-year gizzard shad and crappie provide available prey to crappie from early July through October. Small black crappie will shift to available fish in clearer waters. Age-I black crappie (111-127 mm) taken by midwater trawling at night in Lake Minatare, 
Nebraska (secchi disk, $1.5 \mathrm{~m}$ ) on 25 August 1982 fed on 11-16 mm crappie, and yearling white crappie (125-151 mm) had unidentifiable fish in their stomachs (J. Peterson, A. Hanson, and D. G. Ellison, Nebraska Game and Parks Commission, unpublished). The high availability of small crappie and gizzard shad as prey allowed the transition to fish by crappie during their second summer of life.

Several Nebraska lakes and small flood-control impoundments $(<800$ hectare) exhibit a characteristic crappie population response to the nature of the food resource and the fish population. Water transparency $(0.5-1 \mathrm{~m})$ in most of these lakes is usually of little concern for managing crappie populations. Largemouth bass populations in some of these lakes would be considered undesirable with few bass of quality size (300-380 mm). A look at the size composition of prey in these lakes and in Hayes Center State Lake points to similar problems. Prey size was insufficient for most crappies to maintain good growth and survive beyond $200 \mathrm{~mm}$. Rapid growth rate of young-of-the-year gizzard shad in these lakes limits their value as prey for crappie.

The regulation of energy flow among trophic levels coupled with improved community balance by reducing the number of young crappies could be a key element for effective crappie management in some systems. Desirable crappie populations have been established in small impoundments by implementation of a slot length limit for largemouth bass. Protecting the number of $300-380-\mathrm{mm}$ bass in small impoundments resulted in increased predation on young crappies, reduced intraspecific competition, and alowed the larger crappies to attain harvestable size (Gabelhouse 1984). Management of prey indirectly would improve the energy flow to $>150$ $\mathrm{mm}$ crappie and further increase the system's potential production of harvestable fish. It would appear, though, that increasing the length of the food chain would severely limit the numbers of harvestable crappies in the creel. Trophic dynamic theory predicts that fish production will decrease by an order of magnitude in relation to the ecological efficiency between trophic levels (10-20\%); therefore, production should decrease with an increase in the length of the food chain (Lindeman 1942; Slobodkin 1960). Crappie are not highly adapted to feeding on small zooplankton throughout their life and, more importantly, the volume of food ingested does not increase proportionally to fish weight. Because of a higher metabolic expenditure per unit growth for planktophagic crappie greater than $150 \mathrm{~mm}$, potential production may not exceed the curent production of larger, piscivorous crappie in spite of an extra trophic level in the food chain.

\section{ACKNOWLEDGMENTS}

Monte Madsen, Steven Brezenski, Marvin Miller, and Marlin Miller collected the field data, Christine Mercer prepared the figures. Richard Anderson and Gene Zuerlein reviewed the manuscript. This study was supported by a contribution from Federal Aid in Fish Restoration, Dingell-Johnson Project F-51-R, Nebraska.

\section{REFERENCES}

Anderson, R. O. 1973. Application of theory and research to management of warmwater fish populations. Transactions of the American Fisheries Society $102: 164-171$.

BenNetT, G. W. 1945. Overfishing in a small artificial lake: Onized Lake near Alton, Illinois. Illinois Natural History Survey Bulletin 23:373-406.

Gabelhouse, D. W., JR. 1984. An assessment of crappie stocks in small midwestern private impoundments. North American Journal of Fisheries Management 4:371-384.

Goodson, L. F., JR. 1966. Crappie. Pages 312-332 in A. Calhoun, editor. Inland Fisheries Management. California Department of Fish and Game, Sacramento, California, USA.

Hall, G. E., R. M. Jenkins, and J. C. Finnell. 1954. The influence of environmental conditions upon the growth of white crappie and black crappie in Oklahoma waters. Report 40, Oklahoma Fishery Research Laboratory, Norman, Oklahoma, USA.

HANSON, D. F. 1951. Biology of the white crappie in Illinois. Illinois Natural History Survey Bulletin 25, Article 4:211-265.

KerR, S. R. 1971. Analysis of laboratory experiments on growth efficiency of fishes. Journal of the Fisheries Research Board of Canada 28:801-808.

Lindeman, R. L. 1942. The trophic-dynamic aspect of ecology. Ecology 23:399-418.

Mathur, D., AND T. W. Robbins. 1971. Food habits and feeding chronology of young white crappie, Pomoxis annularis Rafinesque, in Conowingo Reservoir. Transactions of the American Fisheries Society 100:307-311.

Neal, R. A. 1963. Black and white crappies in Clear Lake, 1950-1961. Iowa State Journal of Science 37:425-445.

Paloheimo, J. E., and L. M. Dickie. 1965. Food and growth of fishes. I. A growth curve derived from experimental data. Journal of the Fisheries Research Board of Canada 22:521-542. 
Rutledge, W. P., and J. C. Barron. 1972. The effects of the removal of stunted white crappie on the remaining crappie population of Meridian State Park Lake, Bosque, Texas. Technical Series 12, Texas Parks and Wildlife Department, Austin, Texas, USA.

SeaburG, K. G., and J. B. Moyle. 1964. Feeding habits, digestive rates, and growth of some Minnesota warmwater fishes. Transactions of the American Fisheries Society 93:269-285.

Slobodkin, L. B. 1960 . Ecological energy relation- ships at the population level. American Naturalist 94:213-236.

Starrett, W. C., AND A. W. Fritz. 1965. A biological investigation of the fishes of Lake Chautauqua, Illinois. Illinois Natural History Survey Bulletin 29.

Wright, D. I., W. J. O'Brien, ANd C. Luecke. 1983. A new estimate of zooplankton retention by gill rakers and its ecological significance. Transactions of the American Fisheries Society 112:638-646. 